\title{
How do Citrus Crops Cope with Aluminum Toxicity?
}

\author{
KKIU Arunakumara, Buddhi Charana Walpola ${ }^{1}$, and Min-Ho Yoon $^{1 *}$ \\ Department of Crop Science, Faculty of Agriculture, University of Ruhuna, Mapalana, Kamburupitiya, Sri Lanka \\ ${ }^{1}$ Department of Bio-Environmental Chemistry, College of Agriculture and Life Sciences, Chungnam National University, \\ Daejeon, 305-764, Korea
}

\begin{abstract}
Wordd Agriculture faces daunting challenges in feeding the growing population today. Reduction in arable land extent due to numerous reasons threatens achievement of food and nutritional security. Under this back ground, agricultural use of acidic soils, which account for approximately $40 \%$ of the world arable lands is of utmost important. However, due to aluminum (AI) toxicity and low available phosphorous (P) content, crop production in acidic soils is restricted. Citrus, in this context, gains worldwide recognition as a crop adapted to harsh environments. The present paper reviewed Al toxicity and possible toxicity alleviation tactics in citrus. As reported for many other crops, inhibition of root elongation, photosynthesis and growth is experienced in citrus also due to Al toxicity. Focusing at toxicity alleviation, interaction between boron (B) and $\mathrm{Al}$ as well as phosphorus and Al has been discussed intensively. Al toxicity in citrus could be alleviated by $P$ through increasing immobilization of $\mathrm{Al}$ in roots and $\mathrm{P}$ level in shoots rather than through increasing organic acid secretion, which has been widely reported in other crops. Boron-induced changes in Al speciation and/or sub-cellular compartmentation has also been suggested in amelioration of root inhibition in citrus. Despite the species-dependent manner of response to Al toxicity, many commercially important citrus species can be grown successfully in acidic soils, provided toxicity alleviation Agro-biological tactics such as addition of phosphorous fertilizers are used property.
\end{abstract}

Key words: Acidic soil, Aluminum toxicity, Citrus, Detoxification

\section{Introduction}

Aluminum toxicity in acidic soils Soil acidification, a process associated with leaching of basses, high oxidative biological activities which produce acids, high rainfall and low evaporation and some crop management practices etc. is recognized to be a major constraint in crop production, in particular, in the tropics and subtropics (López and Espinosa, 2000; Matsumoto, 2002; Ishitani et al., 2004). In agricultural lands, crop plants keep absorbing cations (such as $\mathrm{K}^{+}, \mathrm{Ca}^{+2}$ and $\mathrm{Mg}^{+2}$ ) releasing $\mathrm{H}^{+}$to maintain ionic balance in soil-plant environment. Addition of nitrogenous fertilizers may also releases $\mathrm{H}^{+}$through nitrification of ammonium $\left(\mathrm{NH}_{4}{ }^{+}\right)$. Acid-soil syndrome is thus reported in acidic soils, which account for approximately $30 \%$ of the world's total land area.( Kochian et al., 2004; Chen et al., 2012) Furthermore, it has been estimated that over $40 \%$ of the world's potential arable lands are acidic. Crops

\footnotetext{
Received : 2012. 11.9 Accepted : 2012. 2012. 12. 3

*Corresponding author : Phone: +82428216733

E-mail: mhyoon@cnu.ac.kr
}

grown in acidic soils can undergo several difficulties, including toxicity of aluminum $(\mathrm{Al})$, hydrogen $(\mathrm{H})$, and/or manganese $(\mathrm{Mn})$, as well as potential nutrient deficiencies of magnesium $(\mathrm{Mg})$ and calcium $(\mathrm{Ca})$.

In terms of relative abundance, $\mathrm{Al}$ is the third element after oxygen and silicon and the most abundant metal in the earth's crust (Ma and Furukawa, 2003; Matsumoto and Motoda, 2012). It belongs to the non-essential category of metals, thus does not exert any known function in plant metabolism (Wang and Kao, 2004). However, the metal is considered to be the most widespread problem in acid soils, where land use for agricultural purposes was severely affected (Lilienfein et al., 2003). Depending on $\mathrm{pH}, \mathrm{Al}$ exists in a number of different forms in the soil (Wang et al., 2006). Under acidic conditions, $\mathrm{Al}$ is solubilized into $\left[\mathrm{Al}\left(\mathrm{H}_{2} \mathrm{O}\right)_{6}\right]^{3+}$, generally referred to as $\mathrm{Al}^{3+}$, which is highly toxic to many plant species (Éva Darkó et al., 2004). Despite the fact that many plants find it difficult to withstand against the $\mathrm{Al}$ toxicity, it's most common forms i.e. oxides and aluminosilicates are harmless to plants (Ma and Furukawa, 2003; Wang and Kao, 2004). 
Under Al-stress, sensitive plants display a number of toxicity symptoms depending on the species, variety and/or genotype. Inhibition of cell division in the root tip meristem by $\mathrm{Al}^{3+}$ is often reported for many species (Gunsé et al., 2003; Doncheva et al., 2005; Meda and Furlani, 2005). Increased rigidity of the double helix of DNA caused by accumulated $\mathrm{Al}^{3+}$ results in poor cell division in root tip meristem (Meriga et al., 2010). In fact, in many plants, inhibition of root elongation has been reported within a few minutes time even at micromolar concentrations of $\mathrm{Al}^{3+}$ (Matsumoto and Motoda, 2012). The growth of the plant is affected mainly due to poor uptake of moisture and nutrients by injured root tips (Samac and Tesfaye, 2003; Vitorello et al., 2005). In some cases, increased susceptibility to drought stress, lodging and nutrient deficiencies are also reported from affected plants (Sun et al., 2010).

Under this background crop species which can grow on acidic soils gain increasing attention worldwide. In this context, Citrus spp. are widely recognized as hardy species, which can be cultivated successfully on acidic soils (Jiang et al., 2009a).

Citrus crops Citrus, a major group of fruit crops belong to family Rutaceae play a vital role in the achievement of nutritional security. These crops are primarily gained recognition as fruits, which are either eaten alone (sweet orange, tangerine, grapefruit, etc.) as fresh fruit, processed into juice, or added to dishes and beverages (lemon, lime, etc.). In addition to the food value, citrus crops possess medicinal value also, in particular, in traditional medicine (Manner et al., 2006). Out of many species coming under the common name of citrus, Table 1 summarizes several species which are of commercially important.

During last couple of decades, the global production of citrus has experienced an increasing growth. The continuous rise in citrus production is attributed to the increase in land extent under cultivation, change in consumer preference towards fresh and healthy food and rising income level of the consumers (UNCTAD, 2005). As of the latest records, global production and trade of citrus for 2011 has been forecasted at 51.4 million metric tons (MMT) and 3.8 MMT, respectively. Oranges constitute the bulk of the production, accounting for more than half of global citrus production, however, contribution of grapefruit, pommeloes, lemon and limes is also found to be significant (Table 2).

Effect of aluminum on citrus Pereira et al. (2003) investigated the effect $\mathrm{Al}$ on the growth of Citrus limonia Osbeck, Citrus volkameriana Hort. ex Tan, Citrus reshni Hort. ex Tan and Citrus sunki Hort. ex Tan in hydroponic culture and observed reduced growth of the shoot, leaf area ratio and leaf weight ratio under $\mathrm{Al}$-stress. However, the relative growth rate (RGR) of all the rootstocks was found to be increased initially despite the presence of $\mathrm{Al}$ in the nutrient solution, which might be due to initial increase in net photosynthesis rate as reported by Pereira et al. (2000), who investigated gas exchange and chlorophyll fluorescence in four citrus rootstocks under Al-stress. Explaining the results, Pereira et al. (2003) further mentioned that $\mathrm{Al}$ could negatively affect the ability of plants to maintain and, or increase the existing dry matter due to $\mathrm{Al}$-induced enhancement of potential respiratory component of the plant. According to Chen et al. (2005b), growth parameters such as leaf, stem and root fresh and dry mass of citrus plants (Citrus reshni Hort. Ex Tan)

Table 1. Citrus species, their common names and origin (extracted from Manner et al., 2006).

\begin{tabular}{lcc}
\hline \hline Species & Common name & Native origin \\
\hline C. sinensis & Sweet orange & S. China, Indochina \\
C. reticulata & Mandarin & SE Asia \\
C. paradisi & Grapefruit & West Indies \\
C. mitis & Calamondin & China \\
C. medica & Citron & India \\
C. macroptera & Wild orange & Malaysia \\
C. limon & Lemon & SE Asia \\
C. hystrix & Kaffir lime & Malaysia \\
C. grandis & Pummelo & Malaysia \\
C. aurantium & Sour orange & S. China, Indochina \\
C. aurantifolia & Lime & Malesia \\
\hline
\end{tabular}


Table 2. Production of citrus in major producing countries in 2011/2012 (1000 metric tons).

\begin{tabular}{lccc}
\hline \hline Oranges & Grapefruit & Lemons and limes & Tangerines/Mandarins \\
\hline Brazil (19053) & China (3000) & Mexico (1700) & China (15000) \\
United states (8140) & United states (1022) & EU-27 (1316) & EU-27 (3127) \\
China (6600) & South Africa (390) & Argentina (1200) & Japan (1015) \\
EU-27 (5521) & Mexico (300) & Turkey (850) & Turkey (875) \\
Mexico (3200) & Turkey (240) & United states (753) & Morocco (730) \\
Egypt (2350) & Israel (205) & South Africa (260) & Korea, South (645) \\
Turkey (1730) & Argentina (160) & Israel (61) & United states (635) \\
Other (4513) & Other (104) & Other (68) & Other (594) \\
Total (51107) & Total (5421) & Total (6208) & Total (22621) \\
\hline
\end{tabular}

Source: USDA 2012. Citrus world markets and trade. Foreign Agricultural Service.

showed marked reductions compared to control. Furthermore, it has been noticed that reductions in leaf and stem fresh and dry mass were greater than those of the root in response to Al. Confirming these findings, Jiang et al. (2008) reported a reduction in shoot dry mass in Citrus grandis (L.) seedlings irrigated for 5 months with nutrient solution containing different concentrations $(0.2,0.6$ or $1.6 \mathrm{mM})$ of $\mathrm{Al}$. However, no significant decrease in root dry mass has been observed up to $0.6 \mathrm{mM} \mathrm{Al}$ in the nutrient solution. Similar results have been reported by Chen et al. (2009) with Citrus grandis (L.) seedlings irrigated with $\mathrm{Al}$ containing nutrition medium.

Role of boron and phosphorous on aluminum toxicity An investigation was conducted (Jiang et al., 2009b) with Citrus grandis L. seedlings to determine how boron alleviates Al-induced inhibition of root and shoot growth and results confirmed that inhibition of root and shoot growth is not due to Al-induced boron deficiency, but due to $\mathrm{Al}$ toxicity. Their findings on preventive measures of boron are in line with the results of Yu et al. (2009), who conducted a similar study with pea (Pisum sativam). According to Jiang et al. (2009b), boron induced changes in $\mathrm{Al}$ speciation and/or sub-cellular compartmentation would be the reason behind amelioration of root inhibition in citrus, which has previously stated by Corrales et al. (2008) also. However, Jiang et al. (2009b) further reported that boron induced amelioration of shoot growth and photosynthesis inhibition could be due to less $\mathrm{Al}$ accumulation in shoots.

In fact, the ability of boron in alleviation of $\mathrm{Al}$ toxicity has been reported for several other plants including apple (Wojcik, 2003) and wheat (Hossain et al., 2004). However, no ameliorative effects of boron on $\mathrm{Al}$ toxicity could be detected in maize (Wang et al., (2005), which is confirmed by Corrales et al. (2008) as they too have not observed any amelioration effect of boron on inhibition of root growth in maize.

Several possible mechanisms have been proposed in exploring the boron-induced alleviation of $\mathrm{Al}$ toxicity. Ruiz et al. (2006) assessed the Al toxicity in sunflower and suggested that boron- induced enhancement of glutathione (GSH) synthesis as the mechanism, through which boron ameliorate the Al toxicity. As observed previously (Yamamoto et al., 2001; Boscolo et al., 2003), increased concentration of GSH could minimize Al-induced oxidative stress in plants. Putting forward another mechanism for dicots, Stass et al. (2005) stated that boron could decrease in unmethylated pectin in cell walls of root tips discouraging Al binding to apoplastic compartments.

Phosphorus deficiency has been extensively discussed as a key factor attributed to poor crop performances in acidic soils. Inorganic phosphates in acidic soils are associated with iron (Fe) and $\mathrm{Al}$ compounds; whereas calcium $(\mathrm{Ca})$ phosphates are predominant inorganic phosphate form in neutral or calcareous soils (Gyaneshwar et al., 2002). Unfavorable $\mathrm{pH}$ and high reactivity of $\mathrm{Al}$ and $\mathrm{Fe}$ in acidic soils decrease phosphorous availability as well as phosphatic fertilizer efficiency (Hao et al., 2002). Therefore, the majority of applied phosphatic fertilizers are readily fixed in soil and become unavailable to plants. In this context, it is presumed that sufficient $P$ nutrition could guarantee the healthy growth of plants and improve resistance to other abiotic stresses including $\mathrm{Al}$ toxicity.

Several plant species have been employed in elucidating the interaction between added $\mathrm{P}$ and $\mathrm{Al}$ toxicity. Studies with soybean (Liao et al., 2006), rice (Nakagawa et al., 2003) and maize (Gaume et al., 2001) suggested that $P$ 
addition could alleviate $\mathrm{Al}$ toxicity. According to Chen et al. (2012), P-dependent alleviation of Al toxicity is based on two possible mechanisms. Al can be precipitated directly with $\mathrm{P}$ on the root surface, in root cell walls or within root cells or in the soil solution (Silva et al., 2001; Nakagawa et al., 2003; Zheng et al., 2005). As the other possible mechanism, external application of $\mathrm{P}$ could alleviate $\mathrm{Al}$ toxicity indirectly through improving the root morphology, which facilitates nutrient uptake or by secreting special root exudates (Liao et al., 2006).

Concluding their findings of the experiment conducted with $C$. grandis, Jiang et al. (2009a) reported that $P$ could alleviate Al-induced inhibition of growth and photosynthesis through increasing $\mathrm{Al}$ immobilization in roots and $\mathrm{P}$ level in roots and shoots. Yang et al. (2011) too reported that $\mathrm{Al}$ toxicity in citrus (C. grandis and C. sinensis) could be alleviated by $\mathrm{P}$ through increasing immobilization of $\mathrm{Al}$ in roots and $\mathrm{P}$ level in seedlings rather than through increasing organic acid $(\mathrm{OA})$ anion secretion.

Role of nitric oxide on aluminum toxicity Gaseous free radical nitrous oxide (NO) is widely recognized to be involved in resistance mechanism of abiotic-stress in many plants (Hasanuzzaman et al., 2010; Marciano et al., 2010; Siddiqui et al., 2011). In fact, nitric oxide could mediate several physiological and biochemical functions in plants through its role as a signaling molecule (Besson-Bard et al., 2008). Even though enough research evidence on as to how nitric oxide minimize the abiotic stress is yet to receive, several authors reported that nitric oxide is involved in regulating plant's response to salinity (Song et al., 2009), water deficit (Neill et al., 2002) and to Al toxicity (Wang and Yang, 2005).

Al-induced inhibition of root growth was found to be prevented by nitric oxide in Oryza sativa (Marciano et al., 2010); Hibiscus moscheutos (Tian et al., 2007) Cassia tora (Wang and Yang, 2005), Phaseolus vulgaris (Wang et al., (2010) and Citrus grandis (Yang et al., 2012). Al-induced oxidative stress in roots was also reported to be minimized by nitric oxide in Phaseolus vulgaris (Wang et al., (2010) and Cassia tora (Wang and Yang, 2005), where the action of nitric oxide against root growth inhibition was found to be correlated with less $\mathrm{Al}$ accumulation in root apexes. According to Marciano et al. (2010), Al-induced inhibition of seed germination in Oryza sativa can also be prevented by nitric oxide.
Effect of aluminum on $\mathrm{CO}_{2}$ assimilation It has been well documented that photosynthetic apparatus are also affected by the heavy metals toxicity. Heavy metals can interrupt different functions of photosynthesis either directly or indirectly. Light and dark reactions are directly affected by the heavy metals, while reductions in photosynthetic pigments and alteration of stomata function etc., can be considered as indirect effects (Mysliwa-Kurdziel et al., 2004). Though it has been reported previously that heavy metals are not involved in declining the activities of enzymes associated with Calvin cycle, there are enough evidence to say that metal-induced inhibition of enzymes involved in the Calvin cycle is highly responsible for reduced $\mathrm{CO}_{2}$ assimilation (Romanowska, 2002), in particular, Rubisco and PEPcarboxylase (Mysliwa-Kurdziel et al., 2004). Inhibition of enzyme activities of the Calvin cycle and stomatal closure causing short supply of $\mathrm{CO}_{2}$ are often reported (Seregin and Ivanov, 2001; Bertrand and Poirier, 2005; Linger et al., 2005). In addition, Barcelo and Poschenrieder (2004) reported that all most all the components of the photosynthetic apparatus, which include chlorophyll and carotenoid content, chloroplast membrane structure, light-harvesting and oxygen-evolving complexes, photosystems and constituents of the photosynthetic electron transport chain are influenced by heavy metals.

According to Chen et al. (2005a), in response to $\mathrm{Al}, \mathrm{CO}_{2}$ assimilation has decreased in Cleopatra tangerine (Citrus reshni Hort. Ex Tanaka) seedlings which confirmed previous report of Pereira et al. (2000) for four Citrus spp. rootstocks. They have further observed higher intercellular $\mathrm{CO}_{2}$ concentration in Al-treated leaves than in control leaves, which is in agreement with both Pereira et al. (2000) and Peixoto et al. (2002), who too found higher intercellular $\mathrm{CO}_{2}$ concentrations in Al-treated leaves than in control leaves. However, Al-induced stomatal conductance and intercellular $\mathrm{CO}_{2}$ concentration appear to be dependent upon the species and/or cultivar, duration and $\mathrm{Al}$ concentration to which the plant is exposed.

Jiang et al. (2008) recognized Photosystem II (PSII) as the most sensitive photosynthetic apparatus to environmental stress, which is in line with Peixoto et al. (2002), who described the involvement of impaired PSII photochemistry to the reduction of Al-induced photosynthesis in sorghum. In fact, more or less similar comments were made by Chen et al. (2005b) in reporting their findings with citrus. According to them, $\mathrm{Al}$-induced reduction in $\mathrm{CO}_{2}$ assimilation is associated with a possible combination of factors, which 
include reduced electron transport rate through PSII, increased closure of PSII RCs and increased photorespiration.

Mechanisms of aluminum tolerance in citrus As of numerous reports available in the literature on this topic, a considerable number of studies with Al-sensitive and Al-resistant species/cultivars have been conducted and based on the findings, it could be suggested that $\mathrm{Al}$ toxicity and the mechanisms attributed to Al-resistance are extremely complex phenomena (Matsumoto, 2000; Ciamporová, 2002; Éva Darkó et al., 2004). Out of the several possible mechanisms, exclusion is widely accepted as the key contributor in preventing/minimizing $\mathrm{Al}$ toxicity in plant species (Delhaize et al., 2007; Garzon et al., 2011). As reported by many authors, exclusion is expected to occur as a result of one or combination of following processes; exudation of chelating ligands, formation of $\mathrm{pH}$ barrier at the rhizosphere or at root apoplasm, cell wall immobilization, selective permeability of the plasma membrane and Al efflux (Éva Darkó et al., 2004; Wang et al., 2006; Delhaize et al., 2007; Tolra et al., 2009).

Al-induced secretion of organic acid as chelating agents has been shown to be the dominant detoxification mechanism for many plant species (Kochin et al 2004; Poschenrieder et al., 2005; Ma 2007; Maron et al., 2010). Though secretion patterns, temperature sensitivity, response to inhibitors, dose response to $\mathrm{Al}$ etc., depend on the species of concern (Ma 2007; Dong et al., 2008), citrate, malate, and oxalate are reported to be exudated at the rhizosphere and the apoplast of many plant species (Ryan et al., 2001; Poschenrieder et al., 2005). In some plants, secretion of organic acids commences immediately after the exposure of the plant to $\mathrm{Al}$, thus induction of genes is not expected (Ma, 2007). However, there are plants, where Al-induced expression of genes and synthesis of proteins involved in metabolism are needed to initiate secretion of organic acids (Ma et al., 2001).

Among the other mechanisms, rise of $\mathrm{pH}$ at the soil solution has been reported, because, rising $\mathrm{pH}$ could reduce the $\mathrm{Al}$ solubility permitting the formation of less-toxic $\mathrm{Al}$ species such as Al-hydroxides and Al-phosphates etc., (Wang et al., 2006). Exudation of organic acids from roots is also encouraged by elevated $\mathrm{pH}$ at rhizosphere. However, Garzon et al. (2011) elaborating their findings of the experiment carried out with two maize varieties reported that neither rhizosphere $\mathrm{pH}$ changes nor $\mathrm{Al}$-tolerance were clearly related to Al-induced changes in exudation of organic acids into the rhizosphere. Formation of stable complex with ionic $\mathrm{Al}$ is known for some of these organic acids, thus, can prevent binding of $\mathrm{Al}^{3+}$ with extra- and intracellular substances of the root ( $\mathrm{Li}$ et al., 2000). Chelation of $\mathrm{Al}^{3+}$ by other forms of ligands in the cytosol (Ma et al., 2001), Al compartmentation in the vacuole, etc. and several other possible $\mathrm{Al}^{3+}$ protective mechanisms are also found in the literature (Éva Darkó et al., 2004).

With regard to citrus, Yang et al. (2011) reported that $C$. sinensis roots secrete more malate and citrate than $C$. grandis in response to $\mathrm{Al}$ toxicity, however, $\mathrm{Al}$-induced secretion of malate and citrate decreased with increasing $\mathrm{P}$ supply. According to them, involvement of $\mathrm{P}$ in alleviating $\mathrm{Al}$ toxicity through increasing immobilization of $\mathrm{Al}$ in roots is much stronger than toxicity reduction through increasing organic acid anion secretion. Furthermore, the higher Al-tolerance observed in C. sinensis may be due to secretion of organic acids and precipitation of $\mathrm{Al}$ by $\mathrm{P}$ in roots. Chen et al. (2009) also observed Al-induced secretion of malate and citrate in C. grandis. They reported that concentrations of malate and citrate were less affected by the interaction of $\mathrm{P}$ and $\mathrm{Al}$ in roots compared to leaves. According to their findings, concentrations of both organic acids were higher in shoots with $\mathrm{Al}$ than without $\mathrm{Al}$; whereas in roots, both were lower with $\mathrm{Al}$ than without $\mathrm{Al}$. Therefore decreased concentrations of malate and citrate in roots in response to $\mathrm{Al}$ could be due to Al-induced exudation of organic acids under $\mathrm{P}$.

\section{Conclusion}

Crop production in acidic soils is restricted mainly due to $\mathrm{Al}$ toxicity and low available $\mathrm{P}$ content. Citrus by nature is adapted to hardy environments, thus is widely grown in tropical and subtropical areas, where acidic soils are predominately used in Agriculture. However, the degree of adaptation to acidic soils is greatly dependent upon Al-resistance, ability to acquire $\mathrm{P}$ and other nutrients. As elaborated above, though sensitive to Al toxicity, the ability of citrus to withstand against adverse impacts of $\mathrm{Al}$ toxicity through several mechanisms is impressive. Adoption of experimentally proved agro-biological technologies such as use of phosphorous and/or boron in alleviating $\mathrm{Al}$ toxicity is thus encouraged ensuring sustainable citrus production in acidic soils. 


\section{References}

Barcelo, J. and C. Poshenrieder. 2004. Heavy metal stress in plants. From biomolecules to ecosystems In: M. N. V. Prasad (ed.), Structural and Ultrastructural Changes in Heavy Metal Exposed Plants. Springer Berlin, Germany, pp. 223-248.

Bertrand, M. and I. Poirier. 2005. Photosynthetic organisms and excess of metals. Photosynthetica. 43:345-353.

Besson-Bard, A., A. Pugin, and D. Wendehenne. 2008. New insights into nitric oxide signaling in plants. Ann. Rev. Plant Biol. 59:21-39.

Boscolo, P.R.S., M. Menossi, and R.A. Jorge. 2003. Aluminuminduced oxidative stress in maize. Phytochem. 62:181-189.

Chen, L.S., Y.P. Qi, B.R. Smith, and X.H. Liu. 2005 a. Aluminum-induced decrease in $\mathrm{CO}_{2}$ assimilation in Citrus seedlings is unaccompanied by decreased activities of key enzymes involved in $\mathrm{CO}_{2}$ assimilation. Tree Physiol. 25:317324.

Chen, L.S., Y.P. Qi, and X.H. Liu. 2005b. Effects of aluminum on light energy utilization and photoprotective systems in Citrus leaves. Ann. Bot. 96:35-41.

Chen, L.S., N. Tang, H.X. Jiang, L.T. Yang, Q. Li, and B.R. Smith. 2009. Changes inorganic acid metabolism differ between roots and leaves of Citrus grandis in response to phosphorus and aluminum interactions J. Plant Physiol. 166:2023-2034. (abbreviation of journal name is needed)

Chen, R.F., F.L. Zhang, Q.M. Zhang, Q.B. Sun, X.Y. Dong, and R.F. Shen. 2012. Aluminium-phosphorus interactions in plants growing on acid soils: does phosphorus always alleviate aluminium toxicity? J. Sci. Food Agric. 92:995-1000.

Ciamporova, M. 2002. Morphological and structural response of plant roots to aluminum at organ, tissue and cellular levels. Biol. Plant 45:161-171.

Corrales, I., C. Poschenrieder, and J. Barceló. 2008. Boroninduced amelioration of aluminum toxicity in a monocot and a dicot species. J. Plant Physiol. 165:504-513.

Delhaize, E., B.D. Gruber, and P.R. Ryan. 2007. The roles of organic anion permeases in aluminum resistance and mineral nutrition. FEBS Lett. 581:2255-2262.

Doncheva, S., M. Amenós, C. Poschenrieder, and J. Barceló. 2005. Root cell patterning: a primary target for aluminum toxicity in maize. J. Exp. Bot. 56:1213-1220.

Dong, Y.X., R.F. Shen, R.F. Chen, Z.L. Zhu, and J. F. Ma. 2008. Secretion of malate and citrate from roots is related to high Al-resistance in Lespedeza bicolor. Plant Soil. 306:139-147.

Éva Darkó, Helga Ambrus, Éva Stefanovits-Bányai, József Fodor, Ferenc Bakos and Beáta Barnabás. 2004. Aluminium toxicity, Al tolerance and oxidative stress in an Al-sensitive wheat genotype and in Al-tolerant lines developed by in vitro microspore selection. Plant Science. 166:583-591.

Garzon, T., B. Gunse, A. R. Moreno, A. D. Tomos, J. Barcelo, and C. Poschenrieder. 2011. Aluminium-induced alteration of ion homeostasis in root tip vacuoles of two maize varieties differing in Al tolerance. Plant Science. 180:709-715.

Gaume, A., F. Mächler, and E. Frossard. 2001. Aluminum resistance in two cultivars of Zea mays L.: root exudation of organic acids and influence of phosphorus nutrition. Plant Soil. 234:73-81.

Gunsé, B., T. Garzón, and J. Barceló. 2003. Study of aluminum toxicity by means of vital staining profiles in four cultivars of Phaseolus vulgaris L. J. Plant Physiol. 160:1447-1450.

Gyaneshwar, P., K.G. Naresh, L.J. Parekh, and P.S. Poole. 2002. Role of soil microorganisms in improving $\mathrm{P}$ nutrition of plants. Plant Soil. 245:83-93.

Hao, X., C.M. Cho, G.J. Racz, and C. Chang. 2002. Chemical retardation of phosphate diffusion in an acid soil as affected by liming. Nutr. Cyc. Agroecosyst. 64:213-224.

Hasanuzzaman, M., M.A. Hossain, and M. Fujita. 2010. Physiological and biochemical mechanisms of nitric oxide induced abiotic stress tolerance in plants. Am. J. Plant Physiol. 5:295-324.

Hossain, A.K. M.Z., M.A. Hossain, H. Koyama, and T. Hara. 2004. Effects of aluminum and boron supply on growth of seedlings among 15 cultivars of wheat (Triticum aestivum L.) grown in Bangladesh. Soil Sci. Plant Nutr. 50:189-195.

Ishitani, M., I. Rao, P. Wenzl, S. Beebe, and J. Tohme. 2004. Integration of genomics approach with traditional breeding towards improving abiotic stress adaptation: Drought and aluminum toxicity as case studies. Field Crops Res. 90:35-45.

Jiang, H.X., L.S. Chen, J.G. Zheng, H. Han, N. Tang, and B.R. Smith. 2008. Aluminum-induced effects on photosystem II photochemistry in citrus leaves assessed by the chlorophyll a fluorescence transient. Tree Physiol. 28:1863-1871.

Jiang, H.X., N. Tang, J.G. Zheng, Y. Li, and L.S. Chen. 2009a. Phosphorus alleviates aluminum-induced inhibition of growth and photosynthesis in Citrus grandis seedlings. Physiol. Plant. 137:298-311.

Jiang, H.X., N. Tang, J.G. Zheng, Y. Li, and L. S. Chen. 2009b. Antagonistic actions of boron against inhibitory effects of aluminum toxicity on growth, $\mathrm{CO}_{2}$ assimilation, ribulose-1,5bisphosphate carboxylase/oxygenase, and photosynthetic electron transport probed by the JIP-test, of Citrus grandis seedlings. BMC Plant Biol. 9:102-109.

Kochian, L.V., O.A. Hoekenga, and M.A. Piñeros. 2004. How do crop plants tolerate acid soils? Mechanisms of aluminum tolerance and phosphorus efficiency. Annu. Rev. Plant Biol. 55:459-493.

Li, X.F., J.F. Ma, and H. Matsumoto. 2000. Pattern of aluminuminduced secretion of organic acids differs between rye and wheat. Plant Physiol. 123:1537-1543.

Liao, H., H.Y. Wan, J. Shaff, X.R. Wang, X.L. Yan, and L.V. Kochian. 2006. Phosphorus and aluminum interactions in soybean in relation to aluminum tolerance: exudation of specific organic acids from different regions of the intact root system. Plant Physiol. 141:674-684.

Lilienfein, J., R.G. Qualls, S.M. Uselman, and S.D. Bridgham. 2003. Soil formation and organic matter accretion in a young andesitic chronosequence at Mt. Shasta, California. Geoderma. 116:249-264.

Linger, P., A. Ostwald, and J. Haensler. 2005. Cannabis sativa L. growing on heavy metal contaminated soil: growth, cadmium uptake and photosynthesis. Biologia Plantarum. 49:567-576. 
López, A. and J. Espinosa. 2000. Manual on the nutrition and fertilization of banana. National Banana Corporation, Limón, Costa Rica and Potash \& Phosphate Institute Office for Latin America, Quito, Ecuador. pp. 57.

Ma, F.J, P.R. Ryan, and E. Delhaize. 2001 Aluminum tolerance in plants and the complexing role of organic acids. Trends Plant Sci. 6:273-278.

Ma, J.F. 2007. Syndrome of aluminum toxicity and diversity of aluminum resistance in higher plants. Int. Rev. Cytol. 264:225252.

Ma, J.F. and J. Furukawa. 2003. Recent progress in the research of external Al detoxification in higher plants: a mini review. J. Inorg. Biochem. 97:46-51.

Manner, H.I., R.S. Buker, V. Easton Smith, and C.R. Elevitch. 2006. Citrus species (citrus), ver. 2.1. In: Elevitch, C.R. (ed.). Species Profiles for Pacific Island Agroforestry. Permanent Agriculture Resources (PAR), Hōlualoa, Hawai'i. <http://www.traditionaltree.org>.

Marciano, D.P.D.R.O., F.T. Ramos, M.N. Alvim, J.R. Magalhaes, and M.G.C. França. 2010. Nitric oxide reduces the stress effects of aluminum on the process of germination and early root growth of rice. J. Plant Nutr. Soil Sci. 173: 885-891.

Maron, L.G, M.A. Piñeros, C.T. Guimaraes, J.V. Magalhaes, J. K. Pleiman, C.Z. Mao, J. Shaff, S.N.J. Belicuas, and L.V. Kochian. 2010. Two functionally distinct members of the MATE (multi-drug and toxic compound extrusion) family of transporters potentially underlie two major aluminum tolerance QTLs in maize. Plant J. 61:728-740.

Matsumoto, H. 2000. Cell biology of aluminum toxicity and tolerance in higher plants. Int. Rev. Cytol. 200:1-46.

Matsumoto, H. 2002. Plant roots under aluminum stress. Toxicity and tolerance. In: Plants Roots: The Hidden Half. $3^{\text {rd }}$ ed. (Y. Weisel, A. Eshel \& U. Kafkafi, eds). Dekker, New York, USA. pp. 821-838.

Matsumoto, H. and H. Motoda. 2012. Aluminum toxicity recovery processes in root apices; possible association with oxidative stress. Plant Sci. 186:1-8.

Meda, A.R. and P.R. Furlani. 2005. Tolerance to aluminum toxicity by tropical leguminous plants used as cover crops. Braz. Arch. Biol. Technol. 48:309-317.

Meriga, B., I.H. Attitalla, M. Ramgopal, A. Ediga, and P.B. Kavikishor. 2010. Differential tolerance to aluminum toxicity in rice cultivars: Involvement of antioxidative enzymes and possible role of aluminum resistant locus. Academic J. Plant Sci. 3:53-63.

Mysliwa-Kurdziel, B., M.N.V. Prasad, and K. Stralka. 2004. Photosynthesis in heavy metal stress plants. In: Prasad, M. N. V. (Ed) Heavy metal stress in plants, $3^{\text {rd }}$ edn. Springer, Berlin, pp 146-181.

Nakagawa, T., S. Mori, and E. Yoshimura. 2003. Amelioration of aluminum toxicity by pretreatment with phosphate in aluminum-tolerant rice cultivar. J. Plant Nutr. 26:619-628.

Neill, S.J., R. Desikan, A. Clark, and J.T. Hancock. 2002. Nitric oxide is a novel component of abscisic acid signaling in stomatal guard cells. Plant Physiol. 128:13-16.

Peixoto, P.H., F.M. Da Matta, and J. Cambraia. 2002. Responses of the photosynthetic apparatus to aluminum stress in two sorghum cultivars. J. Plant Nutr. 25:821-832.

Pereira, W.E., D.L. de Siqueira, C.A. Martinez, and M. Puiatti. 2000. Gas exchange and chlorophyll fluorescence in four Citrus rootstocks under aluminum stress. J. Plant Physiol. 157:513-520.

Pereira, W.E., D.L. de Siqueira, M. Puiatti, C.A. Martínez, L.C. C. Salomão, and P.R. Cecon. 2003. Growth of citrus rootstocks under aluminum stress in hydroponics. Scientia Agricola. 60:31-41.

Poschenrieder, C., R.P. Tolrà, and J. Barcelo. 2005. A role for cyclic hydroxamates in aluminum resistance in maize. J. Inorg. Biochem. 99:1830-1836.

Romanowska, E. 2002. Gas exchange functions in heavy metal stressed plants. In: Physiology and Biochemistry of Metal Toxicity and Tolerance. M.N.V. Prasad and K. Strzalka. Kluwer (Eds) Academic Publishers, Dordrecht, pp 257-285.

Ruiz, J.M., R.M. Rivero, and L. Romero. 2006. Boron increases synthesis of glutathione in sunflower plants subjected to aluminum stress. Plant Soil. 279:25-30.

Ryan, P.R., E. Delhaize, and D.L. Jones. 2001. Function and mechanism of organic anion exudation from plant roots. Ann. Rev. Plant Physiol. Plant Molec. Biol. 52:527-560.

Samac, D.A. and M. Tesfaye. 2003. Plant improvement for tolerance to aluminum in acid soils; A review. Plant Cell Tissue Organ. Cult. 75:189-207.

Seregin, I.V. and V.B. Ivanov. 2001. Physiological aspects of cadmium and lead toxic effects on higher plants. Rus. J. Plant Physiol. 48:523-544.

Siddiqui, M.H., M.H. Al-Whaibi, and M.O. Basalah. 2011. Role of nitric oxide in tolerance of plants to abiotic stress. Protoplasma. 248:447-455.

Silva, I.R., T.J. Smyth, D.W. Israel, C.D. Raper, and T.W. Rufty. 2001. Magnesium is more efficient than calcium in alleviating aluminum rhizotoxicity in soybean and its ameliorative effect is not explained by the Gouy-Chapman-Stern model. Plant Cell Physiol. 42:538-545.

Song, J., G. Shi, S. Xing, M. Chen, and B. Wang. 2009. Effects of nitric oxide and nitrogen on seedling emergence, ion accumulation, and seedling growth under salinity in the euhalophyte Suaeda salsa. J. Plant Nutr. Soil Sci. 172:544-549.

Stass, A. B. Klug, Z. Cevic, and W.J. Horst. 2005. Boron aluminum interaction in the root tip cell-wall. In: Li C. J, et al. (Eds). Plant nutrition for food security. Human health and environmental protection. Beijing: Tsinghua University Press. pp. 6922-6933.

Sun, P., Q. Y. Tian, J. Chen, and W. H. Zhang. 2010. Aluminuminduced inhibition of root elongation in Arabidopsis is mediated by Ethylene and Auxin. J. Exp. Bot. 61:346-356.

Tian, Q.Y., D.H. Sun, M.G. Zhao, and W.H. Zhang. 2007. Inhibition of nitric oxide synthase (NOS) underlies aluminuminduced inhibition of root elongation in Hibiscus moscheutos. New Phytol. 174:322-331.

Tolra, R, J. Barcelo, and C. Poschenrieder. 2009. Constitutive and aluminum-induced patterns of phenolic compounds in two maize varieties differing in aluminum tolerance. J. Inorg. 
Biochem. 103:1486-1490.

UNCTAD. 2005. Info comm. market information in the commodity area.

USDA. 2012. Citrus world markets and trade. Foreign Agricultural Service, USDA.

Vitorello, V.A., F.R. Capaldi, and V. A. Stefanuto. 2005. Recent advances in aluminum toxicity and resistance in higher plants. Braz. J. Plant Physiol. 17:129-43.

Wang, H.H., J.J. Huang, and Y.R. Bi. 2010. Nitrate reductasedependent nitric oxide production is involved in aluminum tolerance in red kidney bean roots. Plant Sci. 179:281-288.

Wang, J.W. and C.H. Kao. 2004. Reduction of aluminuminhibited root growth of rice seedlings with supplemental calcium, magnesium and organic acids. Crop Environ. Bioinf. 1:191-198.

Wang, P., S. Bi, and W. Han. 2006. Aluminum tolerance of two wheat cultivars (Brevor and Atlas66) in relation to their rhizosphere $\mathrm{pH}$ and organic acids exuded from roots. J. Agric. Food Chem. 54:10033-10039.

Wang, Y.S. and Z.M. Yang. 2005. Nitric oxide reduces aluminum toxicity by preventing oxidative stress in the roots of Cassia tora L. Plant Cell Physiol. 46:1915-1923.

Wang, Y.X., A. Stass, and W.J. Horst. 2005. Assessing the effect of boron on aluminum resistance in maize (Zea mays L.). In: Li CJ, (Ed) Plant nutrition for food security. Human health and environmental protection. Beijing: Tsinghua University Press; pp. 314-315.

Wojcik, P. 2003. Impact of boron on biomass production and nutrition of aluminium-stressed apple rootstocks. J. Plant Nutr. 26:2439-2451.

Yamamoto, Y., Y. Kobayashi, and H. Matsumoto. 2001. Lipid peroxidation is an early symptom triggered by aluminum, but not the primary cause of elongation inhibition in pea roots. Plant Physiol. 125:199-208.

Yang, L.T., H. Jiang, Y.P. Qi, and L.S. Chen. 2012. Differential expression of genes involved in alternative glycolytic pathways, phosphorus scavenging and recycling in response to aluminum and phosphorus interactions in Citrus roots. Mol. Biol. Rep. 39:6353-6366.

Yang, L.T., H.X. Jiang, N. Tang, and L.S. Chen. 2011. Mechanisms of aluminum-tolerance in two species of citrus: Secretion of organic acid anions and immobilization of aluminum by phosphorus in roots. Plant Sci. 180:521-530.

Yu, M., R. Shen, H. Xiao, M. Xu, H. Wang, H. Wang, Q. Zeng, and J. Bian. 2009. Boron alleviates aluminum toxicity in pea (Pisum sativum). Plant Soil. 314:87-98.

Zheng, S.J., J.L. Yang, Y.F. He, X.H. Yu, L. Zhang, and J.F. You. 2005. Immobilization of aluminum with phosphorus in roots is associated with high aluminum resistance in buckwheat. Plant Physiol. 138:297-303. 